\title{
Early and Rapid Engraftment of Bone Marrow-Derived Microglia in Scrapie
}

\author{
Josef Priller, ${ }^{1,2 \star}$ Marco Prinz, ${ }^{1,3 \star}$ Mathias Heikenwalder, ${ }^{1 \star}$ Nicolas Zeller, ${ }^{1}$ Petra Schwarz, ${ }^{1}$ Frank L. Heppner, ${ }^{1}$ and \\ Adriano Aguzzi ${ }^{1}$ \\ ${ }^{1}$ Institute of Neuropathology, Department of Pathology, University of Zurich, 8091 Zurich, Switzerland, ${ }^{2}$ Departments of Psychiatry and Experimental \\ Neurology, Charité-Universitätsmedizin Berlin, 10117 Berlin, Germany, and ${ }^{3}$ Institute of Neuropathology, University of Göttingen, 37075 Göttingen, \\ Germany
}

Prion neuroinvasion is accompanied by maximal activation of microglia, the significance of which for pathogenesis is unknown. Here, we used bone marrow (BM) cells expressing GFP (green fluorescent protein) to study the turnover of microglia in mouse scrapie. We found that $\geq 50 \%$ of all brain microglia were replaced by BM-derived cells before clinical disease onset. In terminally sick mice, microglia density increased threefold to fourfold. Hence BM-derived microglia rapidly and efficaciously colonize the brain in scrapie. Whereas reconstitution of wild-type mice with prion protein-deficient $\left(\operatorname{Prn} p^{\mathrm{o} / \mathrm{o}}\right) \mathrm{BM}$ did not alter scrapie pathogenesis, $\operatorname{Prn} \mathrm{p}^{\mathrm{o} / \mathrm{o}}$ mice transplanted with wild-type BM cells were resistant to peripherally administered prions despite high levels of infectivity in the spleen. Cerebellar homogenates from prion-inoculated $\operatorname{Prnp}^{\mathrm{o} / \mathrm{o}}$ mice reconstituted with $>10 \%$ of wild-type microglia failed to infect transgenic mice overexpressing the cellular prion protein. Hence, in contrast to previous reports, microglia are not competent for efficient prion transport and replication in vivo.

Key words: prion infectivity; microglia; bone marrow transplantation; green fluorescent protein; Purkinje cells; knock-out

\section{Introduction}

Scrapie, chronic wasting disease, and bovine spongiform encephalopathy (BSE), as well as Kuru, iatrogenic and variant Creutzfeldt-Jakob disease (CJD) are fatal neurodegenerative disorders caused by peripheral uptake of prions. After peripheral infection, prions primarily replicate in lymphoid follicles (Aguzzi and Sigurdson, 2004; Aguzzi and Heikenwalder, 2005). The causative agent is thought to be $\operatorname{PrP}^{\mathrm{Sc}}$, a pathological conformer of the cellular prion protein, $\operatorname{PrP}^{\mathrm{C}}$ (Prusiner, 1982; Aguzzi and Polymenidou, 2004). Follicular dendritic cells (FDCs), located in germinal centers of lymphoid organs, are a major site of peripheral $\mathrm{PrP}^{\mathrm{Sc}}$ accumulation (Kitamoto et al., 1991; Brown et al., 1999; Mabbott et al., 2000; Montrasio et al., 2000). Other, as yet poorly defined, immune cells may also replicate the infectious agent in lymphoreticular tissues (Oldstone et al. 2002; Prinz et al., 2002).

Despite prion colonization of peripheral sites, only the CNS shows evident histopathological damage as a result of infection, characterized by vacuolation, neuronal cell loss, and gliosis (Mas-

\footnotetext{
Received May 29, 2006; revised Sept. 26, 2006; accepted Sept. 27, 2006.

This work was supported by an European Molecular Biology Organization fellowship (J.P.), by grants from the Deutsche Forschungsgemeinschaft (J.P., M.P.), and by a National Institutes of Health R01 grant (F.L.H.). M.H. was supported by the Foundation for Research at the Medical Faculty, University of Zurich, and the Ernst-Jung and Bonizzi-Theler Foundations.

*J.P., M.P., and M.H. contributed equally to this work.

Correspondence should be addressed to either of the following: Adriano Aguzzi, Institute of Neuropathology, University of Zurich, Schmelzbergstrasse 12, CH-8091 Zurich, Switzerland, E-mail: adriano.aguzzi@usz.ch; or Josef Priller, Departments of Psychiatry and Experimental Neurology, Charité-Universitätsmedizin Berlin, 10117 Berlin, Germany, E-mail: josef.priller@charite.de.

DOI:10.1523/JNEUROSCI.2275-06.2006

Copyright $\odot 2006$ Society for Neuroscience $\quad 0270-6474 / 06 / 2611753-10 \$ 15.00 / 0$
}

ters and Richardson, 1978). Prion neuroinvasion is thought to occur through sympathetic nerve endings (Glatzel et al., 2001), and the relative distance between FDCs and sympathetic nerves was shown to control the process of neuroinvasion (Prinz et al., 2003). However, the mechanism of transfer of the infectious agent from FDCs to hot spots of innervation and the CNS remains enigmatic (Aguzzi and Heikenwalder, 2005).

Macrophages/microglia may play a role in the dispersion and replication of pathological prion protein. In CJD and scrapie, microglial activation parallels the temporal and spatial pattern of $\mathrm{PrP}^{\mathrm{Sc}}$ deposition and precedes neuronal cell loss and clinical disease (Manuelidis et al., 1997; Williams et al., 1997; Andréoletti et al., 2002b; Hughes et al., 2002). Depending on the agent strainhost combination, microglial activation can precede or follow the accumulation of pathological prion protein (Baker et al., 1999). Perivascular macrophages and microglia express $\operatorname{PrP}^{\mathrm{C}}$ in vivo (Esiri et al., 2002), and $\operatorname{PrP}^{\mathrm{Sc}}$ was detected in microglia from Kuru-, CJD-, BSE-, and scrapie-affected brains (Miyazono et al., 1991; Guiroy et al., 1994; Andréoletti et al., 2002a; González et al., 2005; Kovács et al., 2005).

Neurons and astrocytes respond to prion infection by attracting microglia through fractalkine receptor and chemokine receptor 5 (CCR5) activation in vitro (Hughes et al., 2002; Marella and Chabry, 2004; Lee et al., 2005). Activated glial cells from CJD- and scrapie-infected brains express proinflammatory cytokines, including interleukin (IL)-1 $\beta$, C1q complement, and cathepsin S (Dandoy-Dron et al., 1998; Baker and Manuelidis, 2003). Monocytes are recruited into end-stage scrapie-affected brains in a paradigm of intracerebral prion inoculation (Williams et al., 1995), but the kinetics of myeloid cell recruitment into the CNS after 
peripheral prion inoculation remains unknown. As gene therapies against prions are emerging (Heppner et al., 2001; Mallucci et al., 2003; Meier et al., 2003; Aguzzi and Sigurdson, 2004; Donofrio et al., 2005), targeting of genetically modified cells to the CNS may become instrumental. Here, we explored the possibility that migratory myeloid cells might sense pathological changes in the murine brain after peripheral prion challenge. We found that bone marrow (BM)-derived microglia engraft rapidly and efficaciously in the scrapie-affected brain before the onset of clinical symptoms and coincident with the upregulation of proinflammatory cytokines and chemokines. Surprisingly, no scrapie infectivity was isolated from the engrafted microglia, suggesting (at variance from previous reports) that microglia in vivo lack the intrinsic machinery for efficient prion replication.

\section{Materials and Methods}

Retroviral transduction of hematopoietic cells and bone marrow transplantation. All animals were maintained under specific pathogen-free conditions according to the legislation of the veterinarian office of the Kanton Zurich, Switzerland. Eight- to 12-week-old wild-type (wt: 129Sv $\times$ BL/6) and $\operatorname{Prnp}^{\mathrm{o} / \mathrm{o}}$ mice from the breeding facility of the University of Zurich, Labortierkunde, were transplanted with BM cells that were transduced with a murine stem cell virus (MSCV)-based retroviral vector encoding enhanced green fluorescent protein (GFP) driven by its long terminal repeat (Persons et al., 1997; Priller et al., 2001a,b). The MGirL22Y MSCVbased vector was generated by replacing the neomycin coding cassette in MSCVNEO2.1 (Hawley et al., 1994) with an internal ribosomal entry site from the encephalomyocarditis virus linked to a gene encoding a mutant dihydrofolate reductase (L22Y). The enhanced GFP gene from EGFP-1 (Clontech, Palo Alto, CA) was cloned into the resulting plasmid upstream of the internal ribosomal entry site. High-titer, ecotropic MGirL22Y virus producer cells were generated by transduction of GP plus E86 cells with MGirL22Y vector particles derived by cotransfection of 293T cells with the plasmid containing the MGirL22Y sequences and a helper plasmid encoding the required gag, pol, and env retroviral genes (Persons et al., 1997). The presence of replication-competent retrovirus from the MGirL22Y virus-producer cells was ruled out by testing the ability of conditioned medium from the virus producer cells to mobilize, in a mus dunni test cell line, a recombinant, integrated Moloney leukemia virus (G1Na) that encodes for neomycin phosphotransferase (McLachlin et al., 1993). Conditioned medium from the MGirL22Y virus producer cells was used to infect mus dunni cells harboring two integrated copies of G1Na (provided by Dr. E. F. Vanin, St. Jude's Children's Research Hospital, Memphis, TN). The transduced mus dunni cells were cultured for 3 weeks, and conditioned medium was taken from these cells and tested on naive mus dunni cells for the ability to confer neomycin resistance. No neomycin-resistant colonies were ever detected over multiple independent assays.

Whole BM cells were obtained from femurs and tibias of adult wildtype and $P r n p^{o / o}$ mice treated with $150 \mathrm{mg} / \mathrm{kg}$ 5-fluoruracil (Sigma, Deisenhofen, Germany) for $3 \mathrm{~d}$. After stimulation with $20 \mathrm{ng} / \mathrm{ml} \mathrm{IL-3,} 50$ $\mathrm{ng} / \mathrm{ml} \mathrm{IL-6,} \mathrm{and} 50 \mathrm{ng} / \mathrm{ml}$ stem cell factor (R \& D Systems, Abingdon, UK), adherent and nonadherent whole BM cells were cocultured with irradiated (1300 cGy) GP+E86 virus producer cells. After $48 \mathrm{~h}$ of viral transduction, nonadherent $\mathrm{BM}$ cells were obtained from the cocultures, washed with PBS, counted in Türk solution, and transplanted into lethally irradiated (1100 cGy) wt or Prnp ${ }^{\mathrm{o} / \mathrm{o}}$ mice by tail vein injection $(5 \times$ $10^{6}$ unsorted cells/mouse). For in vitro clonogenic progenitor assays, transduced BM cells were suspended in $2 \mathrm{ml}$ of methylcellulose supplemented with IL-3, IL-6, and stem cell factor (Stem Cell Technologies, Vancouver, British Columbia, Canada), and analyzed after 7-10 d of incubation.

Flow cytometric analysis of GFP expression in peripheral blood leukocytes. Fifteen weeks after bone marrow transplantation (BMT), peripheral blood was obtained from the retro-orbital sinus of methoxyfluraneanesthetized mice and examined by FACS (Becton Dickinson, Mountain View, CA). After erythrocyte lysis using FACS lysis solution (Becton
Dickinson), cells were incubated with CD11b-PE ( $4 \mu \mathrm{g} / \mathrm{ml}$; BD Pharmingen, San Diego, CA) at $4^{\circ} \mathrm{C}$ for $45 \mathrm{~min}$. After sequential washing steps with FACS buffer containing 5\% fetal calf serum (FCS) and 5 mm EDTA, living cells were analyzed on a Becton Dickinson FACSCalibur. Myeloid cells were gated based on their forward- and side-scatter profile, and analyzed for GFP and CD11b expression. Data were evaluated using the CellQuest software.

Inoculation of mice. One week after FACS analysis, chimeric mice were inoculated intraperitoneally with $100 \mu \mathrm{l}$ of brain homogenate containing $6 \log \mathrm{LD}_{50}$ units of the Rocky Mountain Laboratory scrapie strain passage 5 (RML5) as described previously (Kaeser et al., 2001).

Mice were monitored every second day, and scrapie was diagnosed according to clinical criteria (ataxia, kyphosis, priapism, and paraparesis). Mice were killed on the day of onset of terminal signs of scrapie. Attack rate is defined as the percentage of chimeras succumbing to spongiform encephalopathy. Disease latency is expressed in days (means \pm $\mathrm{SD})$.

Glial cell cultures. Primary microglial and astroglial cell cultures were prepared from newborn C57BL/6 mice obtained from the breeding facility of the University of Zurich as described previously (Nolte et al., 1996). Cortical tissue was freed of meninges, trypsinized, and carefully dissociated. The cortical cells were cultured in DMEM supplemented with heat-inactivated $10 \%$ fetal calf serum (Biochrom, Berlin, Germany). After 9-12 d, microglia were separated from the underlying astrocyte monolayer by gentle agitation. An immortalized murine microglial cell line, BV-2 (Bocchini et al., 1992), was cultured in DMEM containing 5\% FCS.

Infectivity bioassays. tga20 mice (Fischer et al., 1996) from the breeding facility of the University of Zurich were inoculated intracerebrally with $1 \%(\mathrm{w} / \mathrm{v})$ cerebellum or spleen homogenates from chimeric mice. Tissues were homogenized in $0.32 \mathrm{M}$ sucrose ( $10 \%$ homogenates). When the solution appeared homogenous, it was centrifuged at $500 \times g$ for $5 \mathrm{~min}$. The supernatants were diluted to $1 \%$ in PBS containing sterile $5 \%$ bovine serum albumin. Supernatants $(30 \mu \mathrm{l})$ were inoculated intracerebrally into groups of four tga 20 mice. Infectivity titers were determined using the relationship $y=11.45-0.088 x\left(y, \log \mathrm{LD}_{50} /\right.$ milliliter of homogenate; $x$, incubation time in days until terminal disease) derived from the method of Prusiner et al. (1982).

$\operatorname{PrP}$ affinity assay and immunoblot analysis. Immunoaffinity purification and immunoblot analysis were performed on tissue homogenates and glial cell lysates as described previously (Prinz and Hanisch, 1999; Fischer et al., 2000). Cells were lysed on ice in $20 \mathrm{~mm}$ Tris-HCl, pH 7.3, containing $140 \mathrm{~mm}$ sodium chloride, $0.5 \%$ Triton X-100, 2 mm sodium orthovanadate, and one tablet per $50 \mathrm{ml}$ Complete protease inhibitors (Boehringer Mannheim, Mannheim, Germany). Minced brain tissue $(10 \% \mathrm{w} / \mathrm{v})$ was homogenized in PBS containing $0.5 \% \mathrm{NP}-40$ and $0.5 \%$ sodium deoxycholate. Extracts were cleared by centrifugation. Supernatants were adjusted to $5 \mathrm{mg} / \mathrm{ml}$ protein and treated with $50 \mu \mathrm{g} / \mathrm{ml}$ proteinase $\mathrm{K}$ or $\mathrm{PBS}$ at $37^{\circ} \mathrm{C}$ for $30 \mathrm{~min}$. Tosyl-activated paramagnetic beads (Dynal, Oslo, Norway) were covalently coupled to mouse serum proteins and preincubated in PBS containing 3\% NP-40 and 3\% Tween 20. After incubation with lysates at $37^{\circ} \mathrm{C}$ for $30 \mathrm{~min}$, beads were washed in PBS and collected using a magnetic particle concentrator. All samples were heated to $95^{\circ} \mathrm{C}$ for $5 \mathrm{~min}$ after addition of $100 \mathrm{~mm}$ phenylmethyl sulfonyl fluoride (Merck, Dietikon, Switzerland) and loading buffer. Fifty micrograms of total protein per sample with or without proteinase $\mathrm{K}$ treatment were electrophoresed through a $12 \%$ SDS-polyacrylamide gel and blotted onto nitrocellulose. After blocking with Tris-buffered saline-Tween (TBS-T) containing 5\% nonfat milk, membranes were incubated with monoclonal antibody ICSM-18 (1:20,000; generously provided by Dr. J. Collinge, Institute of Neurology, Queen Square, UK) for $1 \mathrm{~h}$, washed in TBS-T and developed by enhanced chemiluminescence (Amersham Biosciences, Little Chalfont, UK).

TaqMan analysis of cytokine, chemokine, and chemokine receptor gene expression. Total RNA was isolated from whole brain or cerebellum of chimeric mice at 0,100 , and $150 \mathrm{~d}$ postinoculation (dpi) and terminal disease using TRI Reagent (Invitrogen, San Diego, CA) according to the manufacturer's protocol. Purified total RNA $(1 \mu \mathrm{g})$ was used for the 
generation of cDNA with the QuantiTect kit (Qiagen, Hilden, Germany). TaqMan analysis of the cDNA samples was performed in a thermal cycler (7900HT Fast Real-Time PCR System; Applied Biosystems, Rotkreuz, Switzerland) with a primary incubation step of $2 \mathrm{~min}$ at $50^{\circ} \mathrm{C}$ and denaturation for $10 \mathrm{~min}$ at $95^{\circ} \mathrm{C}$, followed by 40 cycles of $95^{\circ} \mathrm{C}$ for $15 \mathrm{~s}$ and 1 min elongation at $60^{\circ} \mathrm{C}$. For normalization, mouse $\beta$-actin or glyceraldehyde-3-phosphate dehydrogenase (GAPDH) cDNA content was determined in a separate reaction on identical plates. To ensure for the specificity of the products, selected samples were separated on $1 \%$ agarose gels and visualized with ethidium bromide under UV illumination. The following primer sets were used: interferon (IFN)- $\gamma$, forward primer, 5'-TGA ACG CTA CAC ACT GCA TCT TGG-3', and reverse primer, 5'-CGA CTC CTT TTC CGC TTC CTG AG-3'; GAPDH, forward primer, 5'-CCA CCC CAG CAA GGA CAC T-3', and reverse primer, 5'-GAA ATT GTG AGG GAG ATG CTC AGT-3'; tumor necrosis factor (TNF), forward primer, $5^{\prime}$-CAT CTT CTC AAA ATT CGA GTG ACA A- $3^{\prime}$, and reverse primer, $5^{\prime}$-TGG GAG TAG ACA AGG TAC AAC CC-3'; actin, forward primer, 5'-ACC TTC AAC ACC CCA GCC ATG-3', and reverse primer, 5' -GGC CAT CTC TTG CTC GAA GTC-3'; regulated on activation normal T cell expressed and secreted (RANTES)/ CCL5, forward primer, 5' ${ }^{\prime}$ TTT GCC TAC CTC TCC CTA GAG CTG-3', and reverse primer, $5^{\prime}$-ATG CCG ATT TTC CCA GGA CC-3'; CCR1, forward primer, $5^{\prime}$-TTT TAA GGC CCA GTG GGA GTT CAC TCA CCG-3', and reverse primer, 5' -TGG TAT AGC CAC ATG CCT TTG AAA CAG CTG C-3'; CCR3, forward primer, $5^{\prime}$-CTG CTA CAC AGG AAT CAT CAA AAC-3', and reverse primer, 5'-GTT CTT TCC ATT TTC TCA CCA GGA AG-3'; CCR5, forward primer, 5' -TAC CAG ATC TCA GAA AGA AGG TTT TCA TTA- ${ }^{\prime}$, and reverse primer, $5^{\prime}$-GCG TTT GAC CAT GTG TTT TCG GAA GAA CAC T-3'; CX3CL1 (fractalkine), forward primer, $5^{\prime}$-GGG TGG CCA TGT TTG CTT AC-3', and reverse primer, $5^{\prime}$-CAG GCA AGC AGC TCA CAC TG-3'. TaqMan gene expression assays (Applied Biosystems) were used according to the manufacturer's manuals for CXCL9 [monokine induced by IFN- $\gamma$ (MIG)], ID Mm00434946_m1; CXCL2 [growth-related oncogene $\beta$ (GRO- $\beta$ )], ID Mm00436450_m1; CXCL10 [IFN- $\gamma$-inducible protein (IP-10)], ID Mm00445235_m1; and CCL2 [monocyte chemoattractant protein 1 (MCP-1)], ID Mm00441242_m1.

Immunohistochemical analysis. After transcardial perfusion with $4 \%$ paraformaldehyde, $10-20 \mu \mathrm{m}$ cryosections were obtained from the brains. Sections were stained with hematoxylin and eosin for evaluation of neuropathological changes. Adjacent sections were selected for immunohistochemistry and were incubated in PBS containing 10\% normal goat serum and $0.5 \%$ Triton X-100. Primary antibodies were added overnight at a concentration of $5 \mu \mathrm{g} / \mathrm{ml}$ for Ibal (Waco, Osaka, Japan), 5.8 $\mu \mathrm{g} / \mathrm{ml}$ for GFAP (DakoCytomation, Glostrup, Denmark), $2 \mu \mathrm{g} / \mathrm{ml}$ for MAP-2 (microtubule-associated protein 2) (Sigma), 1:25 for major histocompatibility complex (MHC) class II (Serotec, Oxford, UK), $2.5 \mu \mathrm{g} / \mathrm{ml}$ for $2 \mathrm{G} 11$ (generously provided by Dr. P. Berthon, INRA, Nouzilly, France), $1 \mu \mathrm{g} / \mathrm{ml}$ for scrapie-associated fibrils (SAF)-84 (SpiBio, Massy, France), $4 \mu \mathrm{g} / \mathrm{ml}$ for clone POM-1 (Polymenidou et al., 2005), and $1 \mu \mathrm{g} / \mathrm{ml}$ for Ki-67/Tec-3 (DakoCytomation). Texas Red- or Alexa 546-conjugated secondary antibodies (Invitrogen) were added at a concentration of $10 \mu \mathrm{g} / \mathrm{ml}$ for $1 \mathrm{~h}$. For IgG staining, sections were incubated in PBS containing $10 \%$ normal goat serum and treated with $0.3 \% \mathrm{H}_{2} \mathrm{O}_{2}$ for $10 \mathrm{~min}$. A biotinylated goat antimouse IgG antibody (Chemicon, Temecula, CA) was added at a concentration of $2 \mu \mathrm{g} / \mathrm{ml}$ for $90 \mathrm{~min}$, followed by visualization of binding using avidin-biotin-peroxidase complex (DakoCytomation) and 3,3'-diaminobenzidine $/ \mathrm{H}_{2} \mathrm{O}_{2}$ (Walter, Kiel, Germany). Sections were counterstained with hematoxylin. The specificity of all stainings was controlled by omission of primary antibodies. Nuclei were counterstained with $4^{\prime}, 6^{\prime}$-diamidino-2-phenylindole (DAPI) at a concentration of $10 \mu \mathrm{M}$ (Invitrogen). Sections were coverslipped using DakoCytomation Fluorescent Mounting Medium.

Analysis was performed using a conventional fluorescence microscope equipped with a color scanner (Zeiss, Oberkochen, Germany) and a confocal laser-scanning microscope (Leica, Nussloch, Germany). Regional microglia engraftment was quantified by two independent investigators who counted the number of GFP-expressing cells among all
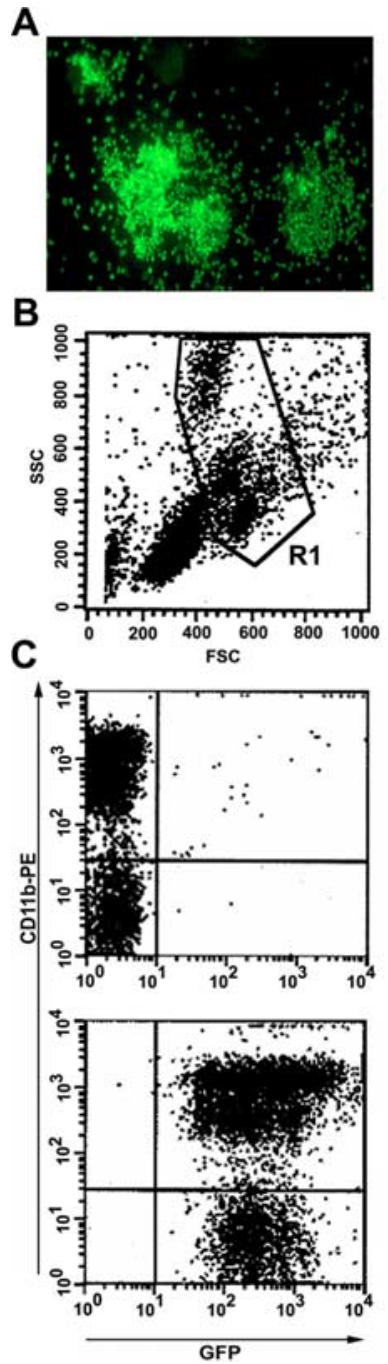

Figure 1. Reconstitution of hematopoiesis with GFP-marked peripheral blood cell progeny. $A, B M$ cells were transduced with a murine stem cell virus-based retroviral vector encoding GFP. Cells were subsequently plated in methylcellulose supplemented with hematopoietic growth factors. After $6 \mathrm{~d}$ in culture, GFP-transduced hematopoietic colonies were visualized under fluorescence microscopy. $\boldsymbol{B}$, Fifteen weeks after transplantation of GFP-transduced BM cells into lethally irradiated mice, myeloid cells were gated based on their forward-scatter (FSC) and side-scatter (SSC) profile. C, Flow cytometry of GFP expression in peripheral blood mononuclear cells revealed that $>99 \%$ of $\mathrm{CD} 11 \mathrm{~b}^{+}$cells expressed GFP in a representative wt $\rightarrow$ wt chimera (bottom). For comparison, no GFP expression was detected in peripheral blood mononuclear cells from a nontransplanted wt mouse (top).

Ibal-immunoreactive microglia per $0.31 \mathrm{~mm}^{2}$ [two to seven randomly selected visual fields at $0,100,150,300 \mathrm{dpi}$ and terminal disease in four different regions of the brain including frontal cortex, brainstem, hippocampus, and cerebellum from the following chimeric mice: $\mathrm{wt} \rightarrow \mathrm{wt}$ $(n=6)$, wt $\rightarrow \mathrm{ko}(n=4)$, and $\mathrm{ko} \rightarrow \mathrm{ko}(n=4)]$. An unpaired Student's $t$ test, ANOVA with Dunnett's post hoc test and rank-based ANOVA with Dunn's test were performed for statistical evaluation of the data. Significance was accepted for $p<0.05$.

\section{Results}

Reconstitution of hematopoiesis with GFP-expressing peripheral blood cell progeny

BM cells from adult wild-type (wt) and $\operatorname{Prnp}^{\mathrm{o} / \mathrm{o}}$ mice were cultured on viral producer cells. Clonogenic progenitor assays revealed that hematopoietic progenitors were successfully transduced with the retrovirus encoding GFP (Fig. $1 A$ ). Four types of BM chimeric mice $(n=92)$ were generated in this study: wt mice 
transplanted with $\mathrm{BM}$ from wt mice $(\mathrm{wt} \rightarrow \mathrm{wt})$, wt mice transplanted with BM from $\operatorname{Prnp}^{\mathrm{o} / \mathrm{o}}$ mice $(\mathrm{ko} \rightarrow \mathrm{wt}), \operatorname{Prnp}^{\mathrm{o} / \mathrm{o}}$ mice transplanted with $\mathrm{BM}$ from wt mice (wt $\rightarrow \mathrm{ko}$ ), and $\operatorname{Prnp}^{\mathrm{o} / \mathrm{o}}$ mice transplanted with BM from $\operatorname{Prnp}^{\mathrm{o} / \mathrm{o}}$ mice (ko $\rightarrow \mathrm{ko}$ ). Fifteen weeks after transplantation of the GFP-transduced BM cells into lethally irradiated recipient mice, the percentages in GFP-marking of peripheral blood $\mathrm{CD}_{11 \mathrm{~b}}{ }^{+}$monocytes were analyzed (Fig. $1 B, C): \mathrm{wt} \rightarrow \mathrm{wt}, 96 \pm 4 \%$; ko $\rightarrow \mathrm{wt}, 98 \pm$ $2 \%$; wt $\rightarrow$ ko, $95 \pm 5 \%$; ko $\rightarrow$ ko, $99 \pm 1 \%$.

\section{Peripheral and central prion} pathogenesis in chimeric mice

To investigate peripheral and central prion pathogenesis, the four different groups of chimeric mice were inoculated intraperitoneally with $6 \log \mathrm{LD}_{50}$ RML5. wt recipient mice succumbed to scrapie $\sim 190 \mathrm{dpi}$, regardless of whether they had been reconstituted with GFPexpressing $\mathrm{BM}$ cells from wt mice (attack rate, 5/5; disease latency, $191 \pm 6 \mathrm{~d}$ ) or from $\operatorname{Prnp}^{\mathrm{o} / \mathrm{o}}$ mice (attack rate, 5/5; disease latency, $189 \pm 3 \mathrm{~d}$ ). In contrast, none of the wt $\rightarrow$ ko $(n=5)$ or $\mathrm{ko} \rightarrow \mathrm{ko}$ $(n=6)$ GFP-chimeras developed scrapie at $300 \mathrm{dpi}$. Susceptibility to scrapie and disease progression was not different in mice that received BMT compared with nontransplanted wt and $\operatorname{Prnp}^{\mathrm{o} / \mathrm{o}}$ mice [for comparison, see Prinz et al. (2002): wt attack rate, 12/12; wt disease latency, $203 \pm 11 \mathrm{~d} ; \operatorname{Prnp}^{\mathrm{o} / \mathrm{o}}$ attack rate, $0 / 6]$.

\section{Spatiotemporal kinetics of microglia engraftment in BM chimeras after peripheral prion inoculation}

Transplantation of GFP-marked BM cells resulted in the engraftment of ramified GFP-expressing microglia in the brains of wt and $\operatorname{Prnp}^{\mathrm{o} / \mathrm{o}}$ mice (Figs. 2-5). These cells expressed the monocyte/ macrophage marker, Ibal (Fig. $2 A-C$ ). At the time of intraperitoneal prion inoculation (i.e., 16 weeks post-BMT), on average $10 \%$ of the microglia expressed GFP in cortex $\left(42 \mathrm{GFP}^{+}\right.$micro$\mathrm{glia} / \mathrm{mm}^{2}$ ), hippocampus (39 $\mathrm{GFP}^{+} \operatorname{microglia} / \mathrm{mm}^{2}$ ), cerebellum $\left(61 \mathrm{GFP}^{+}\right.$microglia/mm $\left.{ }^{2}\right)$, and brainstem $\left(32 \mathrm{GFP}^{+} \mathrm{mi}^{-}\right.$ croglia $/ \mathrm{mm}^{2}$ ) (Figs. $2 A-C, 3$ ). At $100 \mathrm{dpi}$, the level of microglia engraftment was $6.5 \%$ in cortex $\left(30 \mathrm{GFP}^{+}\right.$microglia/mm $\left.{ }^{2}\right)$, $18.5 \%$ in hippocampus $\left(70 \mathrm{GFP}^{+} \mathrm{microglia} / \mathrm{mm}^{2}\right), 13 \%$ in cerebellum $\left(55 \mathrm{GFP}^{+}\right.$microglia $\left./ \mathrm{mm}^{2}\right)$, and $15.5 \%$ in brainstem $(61$ $\mathrm{GFP}^{+}$microglia/mm ${ }^{2}$ ) (Figs. $2 A-C, 3$ ). $\mathrm{Iba}^{+}{ }^{+}$microglia showed an activated morphology at $100 \mathrm{dpi}$, although no obvious signs of brain damage were observed between 0 and 150 dpi (Fig. $4 H$ ) (data not shown) and $\mathrm{PrP}^{\mathrm{Sc}}$ was undetectable in the brain (Fig. $5 A)$. At the time of the first deposition of $\mathrm{PrP}^{\mathrm{Sc}}$ in $w \mathrm{t} \rightarrow$ wt mice at 150 dpi as demonstrated by immunoblot (Fig. $5 A$ ) and histoblot (data not shown), a dramatic increase in the number of GFPexpressing microglia was observed throughout the brain (Fig. $2 A-C)$. Although the total number of microglia remained unchanged (Fig. 3), on average $44 \%$ of the microglia in cortex were $\mathrm{BM}$-derived $\left(156 \mathrm{GFP}^{+}\right.$microglia/ $\left.\mathrm{mm}^{2}\right), 73.5 \%$ of the microglia

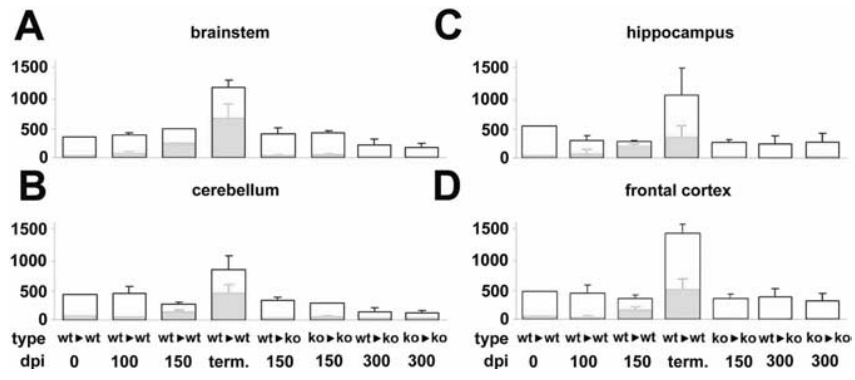

Figure 3. Semiquantitative analysis of regional microglia engraftment at various times after intraperitoneal prion inoculation. The numbers of $\mathrm{Iba}^{+}$microglia (white bars) and $\mathrm{GFP}^{+} \mathrm{Iba}^{+}{ }^{+} \mathrm{BM}$-derived microglia (gray bars) were determined in representative sections from brainstem $(\boldsymbol{A})$, cerebellum $(\boldsymbol{B})$, hippocampus $(\boldsymbol{C})$, and frontal cortex $(\boldsymbol{D})$ of chimeric mice at $0-300 \mathrm{dpi}$ and in terminal stages of scrapie (term.). Data are expressed as microglial cells per square millimeter (means + SD). Note the significant increase in BM-derived microglia at 150 $\mathrm{dpi}$ in wt $\rightarrow$ wt compared with wt $\rightarrow$ ko and ko $\rightarrow$ ko mice $(p<0.05)$. Moreover, the number of microglia, including BM-derived microglia, was significantly increased in terminal (term.) wt $\rightarrow$ wt compared with wt $\rightarrow$ wt mice at $150 \mathrm{dpi}(p<0.05)$ and wt $\rightarrow$ ko and ko $\rightarrow$ ko mice at $300 \mathrm{dpi}(p<0.05)$. The number of cerebellar microglia was significantly decreased in wt $\rightarrow \mathrm{k} 0$ and $\mathrm{ko} \rightarrow$ ko mice at $300 \mathrm{dpi}$ compared with $150 \mathrm{dpi}(p<0.01)$.

in hippocampus $\left(212 \mathrm{GFP}^{+}\right.$microglia/ $\left.\mathrm{mm}^{2}\right), 50 \%$ of the microglia in cerebellum $\left(141 \mathrm{GFP}^{+}\right.$microglia $\left./ \mathrm{mm}^{2}\right)$, and $50 \%$ of the microglia in brainstem $\left(245 \mathrm{GFP}^{+}\right.$microglia $\left./ \mathrm{mm}^{2}\right)$, suggesting that myeloid cells were actively recruited into the brain during the course of disease to replace endogenous microglial cells. No ap- 

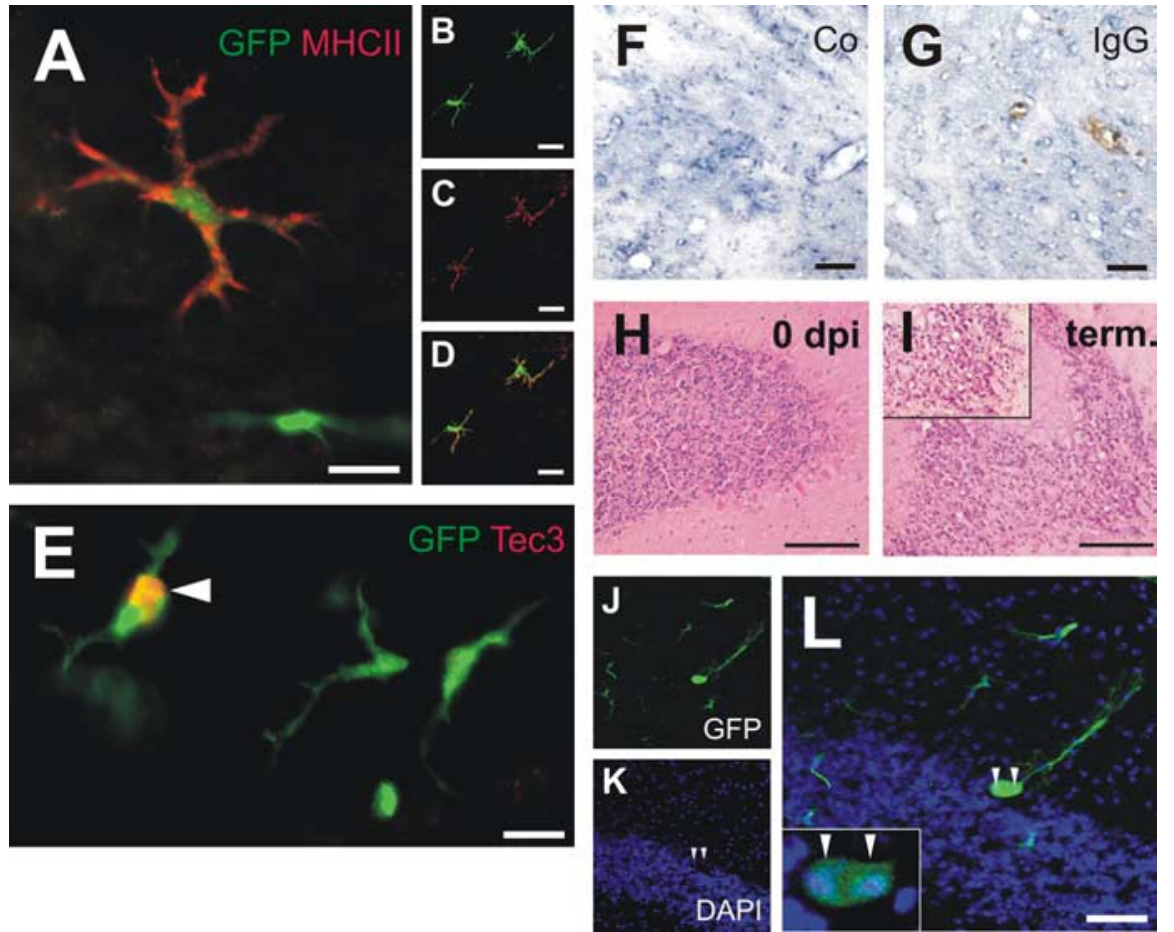

Figure 4. Characterization of BM-derived cells in the scrapie-affected brain. Representative images taken from the cerebellum of a terminally ill $\mathrm{k} 0 \rightarrow$ wt mouse. $A$, A GFP-expressing microglial cell is immunoreactive for MHC class II (red), whereas a neighboring GFP ${ }^{+}$cell does not express MHCII (overlay of GFP and Texas Red fluorescence). $\boldsymbol{B}$, Single optical section through GFPexpressing microglia, which show MHCIll immunoreactivity (C).D, The overlay of the confocal microscopic images in $\boldsymbol{B}$ and $($ reveals coexpression of GFP and MHCII. $\boldsymbol{E}$, A proliferating GFP-expressing microglia shows nuclear Tec3 immunoreactivity (red). Neighboring BM-derived microglia do not express the proliferation marker (overlay of GFP and Texas Red fluorescence). $\boldsymbol{F}, \boldsymbol{G}$, Immunohistochemical staining for $\lg G$ visualized by diaminobenzidine, and counterstaining with hematoxylin reveals the absence of $\lg G$ extravasation into the neuropil (negative control is shown in $\boldsymbol{F}$ ). $\boldsymbol{H}, \boldsymbol{I}$, Hematoxylin and eosin stainings of cerebellar sections from $\mathrm{wt} \rightarrow$ wt mice at $0 \mathrm{dpi}(\boldsymbol{H})$ and terminal disease $(\boldsymbol{I})$. Note the spongiform encephalopathy in $\boldsymbol{I}$ (a higher magnification is shown as an inset). J, Single optical section through a GFP-expressing Purkinje cell, which is surrounded by GFP ${ }^{+}$microglia. $\boldsymbol{K}$, DAPI staining of the nuclei. $\boldsymbol{L}$, The overlay of the confocal microscopic images in $J$ and $\boldsymbol{K}$ reveals that the GFP-expressing Purkinje cell contains two nuclei (indicated by arrowheads), which is suggestive of cell fusion. A higher magnification of the perikaryon is shown as an inset. Scale bars: $A-D, 10 \mu \mathrm{m} ; \boldsymbol{E}, 5 \mu \mathrm{m} ; \boldsymbol{F}, \boldsymbol{G}, 20 \mu \mathrm{m} ; \boldsymbol{H}, \boldsymbol{I}, 100 \mu \mathrm{m}$; (in $\boldsymbol{L}) \boldsymbol{J}-\boldsymbol{L}, 50 \mu \mathrm{m}$.

parent disruption of the blood-brain barrier (BBB) was observed at $0,100,150 \mathrm{dpi}$ and even in terminal stages of disease, as demonstrated by the absence of Ig extravasation (Fig. $4 G$ ). Interestingly, only $3-16 \%$ of the microglia in cortex, hippocampus, cerebellum, and brainstem expressed GFP in the absence of $\operatorname{PrP}^{\mathrm{Sc}}$ at 150 dpi in wt $\rightarrow$ ko and ko $\rightarrow$ ko mice (Fig. 3), indicating that microglia engraftment was consecutive to prion neuropathology and unrelated to the procedure of BMT. With the onset of clinical signs of scrapie and the development of spongiform encephalopathic changes in the brain (Fig. $4 I$ ), a strong proliferative response involving both BM-derived and endogenous microglia led to a threefold to fourfold increase in the overall number of microglial cells in cortex (1440 $\mathrm{Iba}^{+}$microglia/mm ${ }^{2} ; 37 \%$ $\mathrm{GFP}^{+}$), hippocampus (1123 $\mathrm{Ibal}^{+}$microglia/mm ${ }^{2} ; 29 \%$ $\left.\mathrm{GFP}^{+}\right)$, cerebellum $\left(893 \mathrm{Ibal}^{+}\right.$microglia/mm $\left.{ }^{2} ; 61 \% \mathrm{GFP}^{+}\right)$, and brainstem (1171 $\mathrm{Ibal}^{+}$microglia/mm ${ }^{2} ; 54 \% \mathrm{GFP}^{+}$) (Figs. $2 A-C, 3)$. In contrast, the number of $\mathrm{Ibal}^{+}$microglia in wt $\rightarrow$ ko mice at 300 dpi was $413 / \mathrm{mm}^{2}$ in cortex $\left(2 \% \mathrm{GFP}^{+}\right), 250 / \mathrm{mm}^{2}$ in hippocampus $\left(6 \% \mathrm{GFP}^{+}\right), 162 / \mathrm{mm}^{2}$ in cerebellum $(18 \%$ $\left.\mathrm{GFP}^{+}\right)$, and $187 / \mathrm{mm}^{2}$ in brainstem $\left(16 \% \mathrm{GFP}^{+}\right)$(Fig. 3). Similarly, only $6-13 \%$ of the microglia in cortex, hippocampus, cerebellum, and brainstem expressed GFP in ko $\rightarrow$ ko mice at $300 \mathrm{dpi}$ (Fig. 3). The number of Iba1 ${ }^{+}$cerebellar microglia was decreased in $\mathrm{wt} \rightarrow \mathrm{ko}$ and $\mathrm{ko} \rightarrow \mathrm{ko}$ mice at 300 dpi compared with 150 dpi
(Fig. 3). In mice with clinical signs of scrapie, GFP-positive microglia were prominent at sites of astrogliosis (Fig. $2 E, G)$ and expressed the proliferation marker, Tec3 (Fig. 4E). Many of the cells were activated as demonstrated by their MHC class II immunoreactivity (Fig. $4 A-$ $D)$. In the cerebellum, binucleate GFPexpressing Purkinje cells (Fig. $4 J-L$ ) were frequently detected in mice with scrapie.

Induction of cytokine, chemokine, and chemokine receptor mRNA expression in the CNS of BM chimeras after peripheral prion inoculation

TaqMan analysis of proinflammatory cytokine, chemokine, and chemokine receptor gene expression was performed to unravel the molecular mediators involved in microglia recruitment during the course of scrapie. Expression analysis of proinflammatory cytokines in the CNS of wt $\rightarrow$ wt mice failed to demonstrate upregulation of TNF or IFN- $\gamma$ mRNA expression at $100 \mathrm{dpi}$ when compared with 0 dpi (data not shown). However, TNF and IFN- $\gamma$ mRNA expression increased threefold to fourfold at $150 \mathrm{dpi}$ compared with 100 or $0 \mathrm{dpi}$ (wt $\rightarrow$ wt mice). In terminal wt $\rightarrow$ wt mice, TNF mRNA expression further increased to 16-fold over control, whereas IFN- $\gamma$ mRNA remained at levels comparable with 150 dpi. In contrast, $\mathrm{wt} \rightarrow \mathrm{ko}$ or $\mathrm{ko} \rightarrow \mathrm{ko}$ mice did not demonstrate any upregulation of TNF or IFN- $\gamma$ mRNA at 150 dpi. We also investigated mediators likely to be responsible for the engraftment of BM-derived microglia in the CNS. Notably, fractalkine (CX3CL1) and the chemokine receptor CCR1 were already upregulated twofold at $100 \mathrm{dpi}$ in wt $\rightarrow$ wt mice, and fourfold at $150 \mathrm{dpi}$ when compared with 0 dpi in wt $\rightarrow$ wt mice and $150 \mathrm{dpi}$ in $\mathrm{wt} \rightarrow$ ko mice. Interestingly, although unaltered at $100 \mathrm{dpi}$ in $\mathrm{wt} \rightarrow$ wt mice, CCR5 and its ligand, RANTES, were upregulated threefold to fourfold at 150 dpi when compared with wt $\rightarrow$ ko and ko $\rightarrow$ ko mice at $150 \mathrm{dpi}$. In terminal wt $\rightarrow$ wt mice, expression levels of CCR1, CCR5, and RANTES mRNA did not increase further beyond those at $150 \mathrm{dpi}$ in $\mathrm{wt} \rightarrow \mathrm{wt}$ mice. Finally, no induction of CXCL2 (GRO- $\beta$ ), CXCL9 (MIG), CXCL10 (IP-10), and CCL2 (MCP-1) mRNA expression was detected at any time point after peripheral prion inoculation in the brains of wt $\rightarrow \mathrm{wt}$, wt $\rightarrow \mathrm{ko}$, or $\mathrm{ko} \rightarrow$ ko mice. As a positive control, splenic cDNA derived from wild-type mice was analyzed, revealing amplification of CCL2, CXCL9, CXCL10 transcripts, which were not detected in brain.

\section{Engraftment of PrP-expressing bone marrow-derived cells} promotes prion replication in spleen, but not brain of $\operatorname{Prnp}^{\text {o/o }}$ mice

To evaluate the level of PrP expression in microglial cells, we performed immunoaffinity assays and immunoblot analysis on brain homogenates and glial cell lysates. Low levels of PrP expression were detected in primary cultures of murine microglial cells and in the immortalized murine microglial cell line, BV-2 (Fig. 
5D). At 150 dpi, BM-derived microglia/ macrophages were the only cells in the brains of wt $\rightarrow$ ko mice in which PrP immunoreactivity could be detected (Fig. $5 B)$. In scrapie, widespread deposition of $\operatorname{PrP}$ was observed in cerebellar microglia (Fig. 5C).

Because the engraftment of BMderived cells was also high in cerebellum (Fig. 3), we quantified infectivity of cerebella and spleens from chimeric mice by mouse bioassay. All tga20 mice developed scrapie when inoculated intracerebrally with cerebellum homogenates from $\mathrm{wt} \rightarrow \mathrm{wt}$ and $\mathrm{ko} \rightarrow$ wt chimeras killed beyond $150 \mathrm{dpi}$, but not at 50 or $100 \mathrm{dpi}$ (Fig. 6). A trend toward longer incubation times was observed in tga20 mice challenged with cerebellum homogenates from ko $\rightarrow$ wt mice, and the brains of $\mathrm{ko} \rightarrow$ wt mice also contained less $\mathrm{PrP}^{\mathrm{Sc}}$ at 150 dpi compared with wt $\rightarrow$ wt brains (Figs. 5A, 6). In contrast, none of the tga 20 mice inoculated intracerebrally with cerebellum homogenates from $\mathrm{wt} \rightarrow \mathrm{ko}$ and ko $\rightarrow$ ko chimeras killed at 300 dpi developed scrapie when allowed to survive $>190$ d (Fig. 6).

To confirm that reconstitution with wt $\mathrm{BM}$ cells restored prion replication in the spleens of $\operatorname{Prnp}^{\mathrm{o} / \mathrm{o}}$ mice, we transmitted spleen homogenates from BM chimeras after intraperitoneal prion challenge into $\operatorname{tga} 20$ mice. Although the spleens of wt $\rightarrow$ ko chimeras were highly infectious ( $\sim 5.4 \log \mathrm{LD}_{50} / \mathrm{ml}$ of homogenate), none of the tga20 mice inoculated with spleen homogenates from ko $\rightarrow$ ko chimeras at 300 dpi developed disease after $>180 \mathrm{~d}$ (Fig. 6).

\section{Discussion}

For many years, microglia were thought to be essentially sessile and to undergo only minor exchanges with peripheral monocyte-macrophage compartments (Hickey and Kimura, 1988; Lassmann et al., 1993). However, the present data indicate that microglia are extensively recruited from bone marrow to brain during the incubation period of scrapie. The BM-derived microglia appear to replace endogenous microglial cells throughout the brain at the time of $\operatorname{PrP}^{\mathrm{Sc}}$ deposition and before clinical disease onset.

\section{Microglia engraftment in scrapie}

Microglia are the primary immune effector cells in the brain (Kreutzberg, 1996). They continuously survey their microenvironment with motile processes and protrusions, and constitute the first line of defense against invading pathogens (Nimmerjahn et al., 2005). Using GFP-marked BM chimeric mice, we find that resident microglia are replaced with $\mathrm{BM}$-derived microglia at the time of $\mathrm{PrP}^{\mathrm{Sc}}$ deposition in the brain. On average, 54\% of microglia expressed GFP, whereas the absolute number of microglia remained unchanged when $\mathrm{PrP}^{\mathrm{Sc}}$ appeared in the brain. This substantial engraftment of BM-derived microglial cells may have gone undetected in the past because it could only be visualized by genetic labeling of hematopoietic stem cells. Also, it appears to be unrelated to the procedure of BMT because no increase in the percentage of GFP-expressing microglia was observed in the brains of scrapie-inoculated $\mathrm{wt} \rightarrow \mathrm{ko}$ and $\mathrm{ko} \rightarrow$ ko chimeras. Interestingly, the number of microglia decreased with age in cerebellum of $\mathrm{wt} \rightarrow \mathrm{ko}$ mice and $\mathrm{ko} \rightarrow \mathrm{ko}$ mice, ruling out a long-term increase in microglia number as a result of lethal irradiation. These findings are in line with previous studies demonstrating no change or a decrease in the number of microglia in various regions of the aging mouse brain (Long et al., 1998; Ma et al., 2003; Radde et al., 2006). Importantly, wt $\rightarrow$ ko chimeras lacked $\mathrm{PrP}^{\mathrm{Sc}}$ deposition in the brain and did not develop scrapie despite high levels of infectivity in the spleens. Because spleen macrophages were reported to clear inoculum $\mathrm{PrP}^{\mathrm{Sc}}$ and to eliminate newly synthesized $\mathrm{PrP}^{\mathrm{Sc}}$ in the spleen after intraperitoneal scrapie infection (Michel et al., 1987; Beringue et al., 2000a,b), microglia 


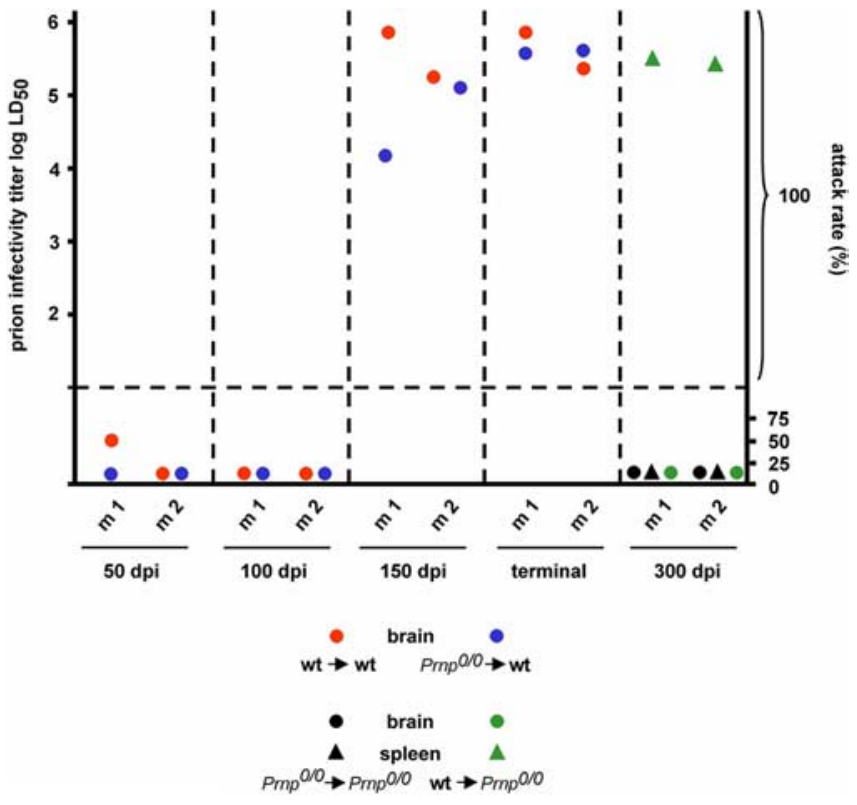

Figure 6. Prion infectivity titers in brains and spleens of chimeric mice after intraperitonea prion inoculation. Tga20 indicator mice were inoculated intracerebrally with $1 \%(\mathrm{w} / \mathrm{v})$ cerebellum or spleen homogenates from BM-chimeric mice ( $n=2$ per genotype and day postinoculation). Titers were determined in cerebellum from wt $\rightarrow$ wt (red circles), $\mathrm{k} 0 \rightarrow \mathrm{wt}$ (blue circles), ko $\rightarrow$ ko (black circles), and wt $\rightarrow$ ko mice (green circles) at 50, 100, 150, 300 dpi and terminal disease. Cerebellum infectivity, leading to an attack rate of $100 \%$, was only detected in $k 0 \rightarrow w t$ mice at $150 \mathrm{dpi}\left(4.2-5.0 \log \mathrm{LD}_{50} / \mathrm{ml}\right)$, wt $\rightarrow$ wt mice at $150 \mathrm{dpi}\left(5.1-5.7 \log \mathrm{LD}_{50} / \mathrm{ml}\right)$, terminal $\mathrm{k} 0 \rightarrow$ wt mice $\left(5.4 \log \mathrm{LD}_{50} / \mathrm{ml}\right)$, and terminal wt $\rightarrow$ wt mice $\left(5.2-5.7 \log \mathrm{LD}_{50} / \mathrm{ml}\right)$. Titers were also determined in spleens from $\mathrm{ko} \rightarrow \mathrm{ko}$ (black triangles) and $\mathrm{wt} \rightarrow$ ko mice (green triangles) at $300 \mathrm{dpi}$. Spleen infectivity was only detected in wt $\rightarrow$ ko mice $\left(5.4 \log \mathrm{LD}_{50} / \mathrm{ml}\right)$

might be involved in the sequestration of disease-associated prion protein in the brain. In the brainstem of naturally scrapie-affected sheep, PrP-immunoreactive material was detected in some microglial cells as large perinuclear granules (Andréoletti et al., 2002a), which resembles the pattern of $\mathrm{PrP}$ immunoreactivity we observed in BM-derived microglia. Uptake of $\operatorname{PrP}^{\mathrm{Sc}}$ may be detrimental to microglial cells because they exhibit tortuous cell processes and occasional intracytoplasmic vacuoles in CJD- and scrapie-affected brains (Williams et al., 1994; von Eitzen et al., 1998). Manipulation of the cytokine and chemokine systems relevant for microglia recruitment (Cook et al., 2001), or of myeloid proliferation and recruitment (Heppner et al., 2005; Simard et al., 2006) may help to clarify whether microglia sequestrate $\operatorname{PrP}^{\mathrm{Sc}}$, and how this affects pathogenesis.

Microglia engraftment in other neurodegenerative conditions Recruitment of myeloid cells into the murine brain and subsequent microglial differentiation has been observed, to various degrees, in a number of neuropathological conditions (Priller et al., 2001b; Massengale et al., 2005). BM-derived microglia were found to accumulate in ventral midbrain and striatum in a mouse model of Parkinson's disease (Kokovay and Cunningham, 2005) or in close proximity to damaged neurons during bacterial meningitis (Djukic et al., 2006). Moreover, BM-derived cells contributed to the recruitment of microglia in response to $\beta$-amyloid $(\mathrm{A} \beta)$ deposition in amyloid precursor protein (APP)/ presenilin-1 (PS1) double transgenic Alzheimer's disease (AD) mice (Malm et al., 2005; Simard et al., 2006). In analogy to our findings in prion disease, microglia engraftment occurred particularly during and after the formation of $\mathrm{A} \beta$ deposits and included activation of glial cells around the deposits. In APP23 transgenic $\mathrm{AD}$ mice, up to one-quarter of neocortical amyloid plaques were associated with BM-derived cells (Stalder et al., 2005). In conjunction with enhanced infiltration of BMderived cells into the hippocampus after lipopolysaccharide injection, the amount of diffuse $\mathrm{A} \beta$ was reduced in APP/PS1 mice (Malm et al., 2005). Importantly, BM-derived microglia appeared to phagocytose $\beta$-amyloid in $\mathrm{AD}$ transgenic mice, whereas resident microglia seemed to be rather ineffective in removing $\beta$-amyloid (Simard et al., 2006). Microglial activation was also observed in APP751 transgenic AD mice, which do not develop plaques but show increased neuronal vulnerability (Koistinaho et al., 2002).

\section{Molecular mediators of microglia recruitment}

Microglia are liaisons between the immune system and the nervous system. Although the molecular mediators of microglia engraftment at sites of prion pathology are still mostly unknown, a number of chemokines and cytokines have been implicated in the disease process. Gene expression studies revealed upregulation of cathepsin S and C1q complement as a characteristic feature of the preinflammatory response of monocytes in murine scrapie (Dandoy-Dron et al., 1998). Fractalkine, which acts as a chemoattractant for microglia, was found to be increased in scrapie (Hughes et al., 2002). Concomitant with the occurrence of neuronal cell loss, microglia, but not bloodborne perivascular cells started to express the fractalkine receptor, CX3CR1. Another important mediator of microglia recruitment in scrapie and CJD may be CCR5. CCR5 transcripts were increased as early as $100 \mathrm{~d}$ after intracerebral prion inoculation in the SY-rat model of CJD (Baker et al., 1999). Moreover, the migration rate of retinal microglia was significantly reduced by a specific CCR5 antagonist after intravitreal injection of scrapie-infected cell homogenate (Marella and Chabry, 2004). Finally, $\operatorname{PrP}^{\mathrm{Sc}}$ itself was recently shown to trigger microglia recruitment in vitro by increasing the expression level of RANTES in neurons via the mitogen-activated protein kinase signaling pathway (Marella et al., 2005). In line with these results, we found an upregulation of CCR1, CCR5, RANTES, and fractalkine mRNA (twofold to fourfold) in the brains of $w t \rightarrow w t$ and $k o \rightarrow$ wt mice at 100-150 dpi (i.e., long before the appearance of clinical signs of scrapie). The induction of chemokine and chemokine receptor mRNA was accompanied by increased gene expression of the proinflammatory cytokines TNF and IFN- $\gamma$.

In addition, we detected $\mathrm{MHC}$ class II antigen expression on BM-derived microglia in scrapie. Notably, MHC class II-positive microglia were also found to accumulate during the development of spongiform changes in the cortex of CJD patients (von Eitzen et al., 1998).

\section{Absence of prion replication in microglia}

One of the most surprising findings of the present study is the inability of BM-derived microglia to replicate pathological prion protein. Despite high levels of infectivity in the periphery, $10 \%$ wild-type microglia from wt $\rightarrow$ ko chimeras failed to infect tga 20 mice in bioassays. How can these results be reconciled with the report that microglial cultures obtained from CJD-infected mice were as infectious as the starting brain homogenate despite 50fold lower expression levels of PrP (Baker et al., 2002)? For one thing, $5 \%$ of the cells in culture were not microglia or monocytes/ macrophages (Baker et al., 2002), and these contaminating cells may have replicated prions. Also, Baker and colleagues used a prion strain different from the one we used: it is not impossible 
that the two strains differ in their cell tropism. The number of wild-type microglia in our cerebellar transmission experiments was comparatively low. We estimate that 50-100 wildtype microglia were transplanted. However, the tga 20 infectivity bioassay is able to detect prion infectivity in as low as $10^{-7}$-fold dilutions of a $1 \%$ brain homogenate derived from a terminally sick CD-1 mouse inoculated with RML (Kaeser et al., 2001). Finally, microglia could have a dual response to prion infection. Relatively small amounts of prion infectivity, as they may occur in vivo during extraneural infection and neuroinvasion, might be taken up and digested by microglia. In contrast, nonphysiologically large amounts of prions, as in the case of experimental exposure of cultured microglia to scrapie-infected brain homogenate, may saturate any "prion clearance" capacity of microglia and lead to prion replication. According to the latter hypothesis, the response of microglia to prions may be dose dependent.

Several previous reports have indicated that infectibility, incubation period, and lesion distribution in scrapie are unaffected by irradiation and BMT (Williams et al., 1995; Fraser et al., 1996; Blättler et al., 1997). The association of reactive microglia with thin-walled vessels in CJD-infected rat brain suggested entry (macrophage derivatives) from the bloodstream (Manuelidis et al., 1997). Interestingly, we found no evidence for BBB impairment in scrapie-inoculated BM chimeric mice at any time point, which is in line with previous reports excluding BBB leakage in tga20 and wild-type mice with clinical symptoms of scrapie (Eikelenboom et al., 1987; Brandner et al., 1998). Magnetic resonance imaging studies of patients with CJD revealed T2hyperintensities without significant BBB disruption (Yoon et al., 1995; Finkenstaedt et al., 1996). However, some studies did report patchy BBB leakage in scrapie (Wisniewski et al., 1983; Chung et al., 1995), particularly in the cerebellum (Vorbrodt et al., 1997).

In this study, we demonstrate that BM-derived cells sense early pathological changes in the brain during the incubation period of scrapie. Concomitant with the deposition of $\mathrm{PrP}^{\mathrm{Sc}}$, they engraft throughout the CNS in substantial numbers as microglia. Our findings may be relevant to other neurodegenerative disorders involving abnormal protein aggregation, including $\mathrm{AD}$, in which BM-derived microglia were recently shown to phagocytose $\beta$-amyloid. Because of their efficient engraftment in host brains, hematopoietic cells may ultimately be exploited for gene therapybased delivery of biotherapeutics in prion diseases and other neurodegenerative disorders.

\section{References}

Aguzzi A, Heikenwalder M (2005) Prions, cytokines, and chemokines: a meeting in lymphoid organs. Immunity 22:145-154.

Aguzzi A, Polymenidou M (2004) Mammalian prion biology: one century of evolving concepts. Cell 116:313-327.

Aguzzi A, Sigurdson CJ (2004) Antiprion immunotherapy: to suppress or to stimulate? Nat Rev Immunol 4:725-736.

Andréoletti O, Berthon P, Levavasseur E, Marc D, Lantier F, Monks E, Elsen JM, Schelcher F (2002a) Phenotyping of protein-prion (PrPsc)accumulating cells in lymphoid and neural tissues of naturally scrapieaffected sheep by double-labeling immunohistochemistry. J Histochem Cytochem 50:1357-1370.

Andréoletti O, Levavasseur E, Uro-Coste E, Tabouret G, Sarradin P, Delisle MB, Berthon P, Salvayre R, Schelcher F, Negre-Salvayre A (2002b) Astrocytes accumulate 4-hydroxynonenal adducts in murine scrapie and human Creutzfeldt-Jakob disease. Neurobiol Dis 11:386-393.

Baker CA, Manuelidis L (2003) Unique inflammatory RNA profiles of microglia in Creutzfeldt-Jakob disease. Proc Natl Acad Sci USA 100:675-679.
Baker CA, Lu ZY, Zaitsev I, Manuelidis L (1999) Microglial activation varies in different models of Creutzfeldt-Jakob disease. J Virol 73:5089-5097.

Baker CA, Martin D, Manuelidis L (2002) Microglia from CreutzfeldtJakob disease-infected brains are infectious and show specific mRNA activation profiles. J Virol 76:10905-10913.

Beringue V, Demoy M, Lasmezas CI, Gouritin B, Weingarten C, Deslys JP, Andreux JP, Couvreur P, Dormont D (2000a) Role of spleen macrophages in the clearance of scrapie agent early in pathogenesis. J Pathol 190:495-502.

Beringue V, Adjou KT, Lamoury F, Maignien T, Deslys JP, Race R, Dormont D (2000b) Opposite effects of dextran sulfate 500, the polyene antibiotic MS-8209, and Congo red on accumulation of the protease-resistant isoform of PrP in the spleens of mice inoculated intraperitoneally with the scrapie agent. J Virol 74:5432-5440.

Blättler T, Brandner S, Raeber AJ, Klein MA, Voigtlander T, Weissmann C, Aguzzi A (1997) PrP-expressing tissue required for transfer of scrapie infectivity from spleen to brain. Nature 389:69-73.

Bocchini V, Mazzolla R, Barluzzi R, Blasi E, Sick P, Kettenmann H (1992) An immortalized cell line expresses properties of activated microglial cells. J Neurosci Res 31:616-621.

Brandner S, Isenmann S, Kuhne G, Aguzzi A (1998) Identification of the end stage of scrapie using infected neural grafts. Brain Pathol $8: 19-27$.

Brown KL, Stewart K, Ritchie DL, Mabbott NA, Williams A, Fraser H, Morrison WI, Bruce ME (1999) Scrapie replication in lymphoid tissues depends on prion protein-expressing follicular dendritic cells. Nat Med 5:1308-1312.

Chung YL, Williams A, Beech JS, Williams SC, Bell JD, Cox IJ, Hope J (1995) MRI assessment of the blood-brain barrier in a hamster model of scrapie. Neurodegeneration 4:203-207.

Cook DN, Chen SC, Sullivan LM, Manfra DJ, Wiekowski MT, Prosser DM, Vassileva G, Lira SA (2001) Generation and analysis of mice lacking the chemokine fractalkine. Mol Cell Biol 21:3159-3165.

Dandoy-Dron F, Guillo F, Benboudjema L, Deslys JP, Lasmezas C, Dormont D, Tovey MG, Dron M (1998) Gene expression in scrapie. Cloning of a new scrapie-responsive gene and the identification of increased levels of seven other mRNA transcripts. J Biol Chem 273:7691-7697.

Djukic M, Mildner A, Schmidt H, Czesnik D, Brück W, Priller J, Nau R, Prinz M (2006) Bone marrow-derived microglia significantly contribute to the pathology following Streptococcus pneumoniae meningitis in mice. Brain 129:2394-2403.

Donofrio G, Heppner FL, Polymenidou M, Musahl C, Aguzzi A (2005) Paracrine inhibition of prion propagation by anti-PrP single-chain Fv miniantibodies. J Virol 79:8330-8338.

Eikelenboom P, Scott JR, McBride PA, Rozemuller JM, Bruce ME, Fraser H (1987) No evidence for involvement of plasma proteins or blood-borne cells in amyloid plaque formation in scrapie-affected mice. An immunohistoperoxidase study. Virchows Arch B Cell Pathol Incl Mol Pathol 53:251-256.

Esiri MM, Carter J, Ironside JW (2002) Macrophage and microglial cell immunoreactivity for $\operatorname{Pr} \mathrm{P}(\mathrm{c})$ in a random post-mortem population. Neuropathol Appl Neurobiol 28:79-82.

Finkenstaedt M, Szudra A, Zerr I, Poser S, Hise JH, Stoebner JM, Weber T (1996) MR imaging of Creutzfeldt-Jakob disease. Radiology 199:793-798.

Fischer M, Rulicke T, Raeber A, Sailer A, Moser M, Oesch B, Brandner S, Aguzzi A, Weissmann C (1996) Prion protein (PrP) with aminoproximal deletions restoring susceptibility of PrP knockout mice to scrapie. EMBO J 15:1255-1264.

Fischer MB, Roeckl C, Parizek P, Schwarz HP, Aguzzi A (2000) Binding of disease-associated prion protein to plasminogen. Nature 408:479-483.

Fraser H, Brown KL, Stewart K, McConnell I, McBride P, Williams A (1996) Replication of scrapie in spleens of SCID mice follows reconstitution with wild type mouse bone marrow. J Gen Virol 77:1935-1940.

Glatzel M, Heppner FL, Albers KM, Aguzzi A (2001) Sympathetic innervation of lymphoreticular organs is rate limiting for prion neuroinvasion. Neuron 31:25-34.

González L, Martin S, Houston FE, Hunter N, Reid HW, Bellworthy SJ, Jeffrey M (2005) Phenotype of disease-associated PrP accumulation in the 
brain of bovine spongiform encephalopathy experimentally infected sheep. J Gen Virol 86:827-838.

Guiroy DC, Wakayama I, Liberski PP, Gajdusek DC (1994) Relationship of microglia and scrapie amyloid-immunoreactive plaques in kuru, Creutzfeldt-Jakob disease and Gerstmann-Straussler syndrome. Acta Neuropathol (Berl) 87:526-530.

Hawley RG, Lieu FHL, Fong AZC, Hawley TS (1994) Versatile retroviral vectors for potential use in gene therapy. Gene Ther 1:136-138.

Heppner FL, Musahl C, Arrighi I, Klein MA, Rulicke T, Oesch B, Zinkernagel RM, Kalinke U, Aguzzi A (2001) Prevention of scrapie pathogenesis by transgenic expression of anti-prion protein antibodies. Science 294:178-182.

Heppner FL, Greter M, Marino D, Falsig J, Raivich G, Hovelmayer N, Waisman A, Rulicke T, Prinz M, Priller J, Becher B, Aguzzi A (2005) Experimental autoimmune encephalomyelitis repressed by microglial paralysis. Nat Med 11:146-152.

Hickey WF, Kimura H (1988) Perivascular microglial cells of the CNS are bone marrow-derived and present antigen in vivo. Science 239:290-292.

Hughes PM, Botham MS, Frentzel S, Mir A, Perry VH (2002) Expression of fractalkine (CX3CL1) and its receptor, CX3CR1, during acute and chronic inflammation in the rodent CNS. Glia 37:314-327.

Long JM, Kalehua AN, Muth NJ, Calhoun ME, Jucker M, Hengemihle JM, Ingram DK, Mouton PR (1998) Stereological analysis of astrocyte and microglia in aging mouse hippocampus. Neurobiol Aging 19:497-503.

Kaeser PS, Klein MA, Schwarz P, Aguzzi A (2001) Efficient lymphoreticular prion propagation requires $\operatorname{PrP}(\mathrm{c})$ in stromal and hematopoietic cells. J Virol 75:7097-7106.

Kitamoto T, Muramoto T, Mohri S, Doh-Ura K, Tateishi J (1991) Abnormal isoform of prion protein accumulates in follicular dendritic cells in mice with Creutzfeldt-Jakob disease. J Virol 65:6292-6295.

Koistinaho M, Kettunen MI, Goldsteins G, Keinanen R, Salminen A, Ort M, Bures J, Liu D, Kauppinen RA, Higgins LS, Koistinaho J (2002) Betaamyloid precursor protein transgenic mice that harbor diffuse A beta deposits but do not form plaques show increased ischemic vulnerability: role of inflammation. Proc Natl Acad Sci USA 99:1610-1615.

Kokovay E, Cunningham LA (2005) Bone marrow-derived microglia contribute to the neuroinflammatory response and express iNOS in the MPTP mouse model of Parkinson's disease. Neurobiol Dis 19:471-478.

Kovács GG, Preusser M, Strohschneider M, Budka H (2005) Subcellular localization of disease-associated prion protein in the human brain. Am J Pathol 166:287-294.

Kreutzberg GW (1996) Microglia: a sensor for pathological events in the CNS. Trends Neurosci 19:312-318.

Lassmann H, Schmied M, Vass K, Hickey WF (1993) Bone marrow derived elements and resident microglia in brain inflammation. Glia 7:19-24.

Lee HP, Jun YC, Choi JK, Kim JI, Carp RI, Kim YS (2005) The expression of RANTES and chemokine receptors in the brains of scrapie-infected mice. J Neuroimmunol 158:26-33.

Ma L, Morton AJ, Nicholson LFB (2003) Microglia density decreases with age in a mouse model of Huntington's disease. Glia 43:274-280.

Mabbott NA, Mackay F, Minns F, Bruce ME (2000) Temporary inactivation of follicular dendritic cells delays neuroinvasion of scrapie. Nat Med 6:719-720.

Mallucci G, Dickinson A, Linehan J, Klohn PC, Brandner S, Collinge J (2003) Depleting neuronal $\operatorname{PrP}$ in prion infection prevents disease and reverses spongiosis. Science 302:871-874.

Malm TM, Koistinaho M, Parepalo M, Vatanen T, Ooka A, Karlsson S, Koistinaho J (2005) Bone-marrow-derived cells contribute to the recruitment of microglial cells in response to beta-amyloid deposition in APP/PS1 double transgenic Alzheimer mice. Neurobiol Dis 18:134-142.

Manuelidis L, Fritch W, Xi YG (1997) Evolution of a strain of CJD that induces BSE-like plaques. Science 277:94-98.

Marella M, Chabry J (2004) Neurons and astrocytes respond to prion infection by inducing microglia recruitment. J Neurosci 24:620-627.

Marella M, Gaggioli C, Batoz M, Deckert M, Tartare-Deckert S, Chabry J (2005) Pathological prion protein exposure switches on neuronal mitogen-activated protein kinase pathway resulting in microglia recruitment. J Biol Chem 280:1529-1534.
Massengale M, Wagers AJ, Vogel H, Weissman IL (2005) Hematopoietic cells maintain hematopoietic fates upon entering the brain. J Exp Med 201:1579-1589.

Masters CL, Richardson Jr EP (1978) Subacute spongiform encephalopathy (Creutzfeldt-Jakob disease). The nature and progression of spongiform change. Brain 101:333-344.

McLachlin JR, Mittereder N, DaucheMB, Kadan M, Eglitis MA (1993) Factors affecting retroviral vector function and structural integrity. Virology 195:1-5.

Meier P, Genoud N, Prinz M, Maissen M, Rulicke T, Zurbriggen A, Raeber AJ, Aguzzi A (2003) Soluble dimeric prion protein binds $\operatorname{PrP}(\mathrm{Sc})$ in vivo and antagonizes prion disease. Cell 113:49-60.

Michel B, Tamalet J, Bongrand P, Gambarelli D, Gastaut JL (1987) Role of phagocytes in experimental scrapie in hamsters. Rev Neurol (Paris) 143:526-531.

Miyazono M, Iwaki T, Kitamoto T, Kaneko Y, Doh-ura K, Tateishi J (1991) A comparative immunohistochemical study of Kuru and senile plaques with a special reference to glial reactions at various stages of amyloid plaque formation. Am J Pathol 139:589-598.

Montrasio F, Frigg R, Glatzel M, Klein MA, Mackay F, Aguzzi A, Weissmann C (2000) Impaired prion replication in spleens of mice lacking functional follicular dendritic cells. Science 288:1257-1259.

Nimmerjahn A, Kirchhoff F, Helmchen F (2005) Resting microglial cells are highly dynamic surveillants of brain parenchyma in vivo. Science 308:1314-1318.

Nolte C, Moller T, Walter T, Kettenmann H (1996) Complement 5a controls motility of murine microglial cells in vitro via activation of an inhibitory G-protein and the rearrangement of the actin cytoskeleton. Neuroscience 73:1091-1107.

Oldstone MB, Race R, Thomas D, Lewicki H, Homann D, Smelt S, Holz A, Koni P, Lo D, Chesebro B, Flavell R (2002) Lymphotoxin-alpha- and lymphotoxin-beta-deficient mice differ in susceptibility to scrapie: evidence against dendritic cell involvement in neuroinvasion. J Virol 76:4357-4363.

Persons DA, Allay JA, Allay ER, Smeyne RJ, Ashmun RA, Sorrentino BP, Nienhuis AW (1997) Retroviral-mediated transfer of the green fluorescent protein gene into murine hematopoietic cells facilitates scoring and selection of transduced progenitors in vitro and identification of genetically modified cells in vivo. Blood 90:1777-1786.

Polymenidou M, Stoeck K, Glatzel M, Vey M, Bellon A, Aguzzi A (2005) Coexistence of multiple PrPSc types in invividuals with Creutzfeld-Jakob disease. Lancet Neurol 4:805-814.

Priller J, Persons DA, Klett FF, Kempermann G, Kreutzberg GW, Dirnagl U (2001a) Neogenesis of cerebellar Purkinje neurons from gene-marked bone marrow cells in vivo. J Cell Biol 155:733-738.

Priller J, Flügel A, Wehner T, Boentert M, Haas CA, Prinz M, Fernandez-Klett F, Prass K, Bechmann I, de Boer BA, Frotscher M, Kreutzberg GW, Persons DA, Dirnagl U (2001b) Targeting gene-modified hematopoietic cells to the central nervous system: use of green fluorescent protein uncovers microglial engraftment. Nat Med 7:1356-1361.

Prinz M, Hanisch UK (1999) Murine microglial cells produce and respond to interleukin-18. J Neurochem 72:2215-2218.

Prinz M, Montrasio F, Klein MA, Schwarz P, Priller J, Odermatt B, Pfeffer K, Aguzzi A (2002) Lymph nodal prion replication and neuroinvasion in mice devoid of follicular dendritic cells. Proc Natl Acad Sci USA 99:919-924.

Prinz M, Heikenwalder M, Junt T, Schwarz P, Glatzel M, Heppner FL, Fu YX, Lipp M, Aguzzi A (2003) Positioning of follicular dendritic cells within the spleen controls prion neuroinvasion. Nature 425:957-962.

Prusiner SB (1982) Novel proteinaceous infectious particles cause scrapie. Science 216:136-144.

Prusiner SB, Cochran SP, Groth DF, Downey DE, Bowman KA, Martinez HM (1982) Measurement of the scrapie agent using an incubation time interval assay. Ann Neurol 11:353-358.

Radde R, Bolmont T, Kaeser SA, Coomaraswamy J, Lindau D, Stoltze L, Calhoun ME, Jäggi F, Wolburg H, Gengler S, Haass C, Ghetti B, Czech C, Hölscher C, Mathews PM, Jucker M (2006) A $\beta$ 42-driven cerebral amyloidosis in transgenic mice reveals early and robust pathology. EMBO Rep 7:940-946.

Simard AR, Soulet D, Gowing G, Julien J-P, Rivest S (2006) Bone marrowderived microglia play a critical role in restricting senile plaque formation in Alzheimer's disease. Neuron 49:489-502. 
Stalder AK, Ermini F, Bondolfi L, Krenger W, Burbach GJ, Deller T, Coomaraswamy J, Staufenbiel M, Landmann R, Jucker M (2005) Invasion of hematopoietic cells into the brain of amyloid precursor protein transgenic mice. J Neurosci 25:11125-11132.

von Eitzen U, Egensperger R, Kösel S, Grasbon-Frodl EM, Imai Y, Bise K, Kohsaka S, Mehraein P, Graeber MB (1998) Microglia and the development of spongiform change in Creutzfeldt-Jakob disease. J Neuropathol Exp Neurol 57:246-256.

Vorbrodt AW, Dobrogowska DH, Tarnawski M, Meeker HC, Carp RI (1997) Immunocytochemical evaluation of blood-brain barrier to endogenous albumin in scrapie-infected mice. Acta Neuropathol (Berl) 93:341-348.

Williams A, Lucassen PJ, Ritchie D, Bruce M (1997) PrP deposition, micro- glial activation, and neuronal apoptosis in murine scrapie. Exp Neurol 144:433-438.

Williams AE, Lawson LJ, Perry VH, Fraser H (1994) Characterization of the microglial response in murine scrapie. Neuropathol Appl Neurobiol 20:47-55.

Williams AE, Ryder S, Blakemore WF (1995) Monocyte recruitment into the scrapie-affected brain. Acta Neuropathol (Berl) 90:164-169.

Wisniewski HM, Lossinsky AS, Moretz RC, Vorbrodt AW, Lassmann H, Carp RI (1983) Increased blood-brain barrier permeability in scrapieinfected mice. J Neuropathol Exp Neurol 42:615-626.

Yoon SS, Chan S, Chin S, Lee K, Goodman RR (1995) MRI of CreutzfeldtJakob disease: asymmetric high signal intensity of the basal ganglia. Neurology 45:1932-1933. 